\title{
2017 Iraqi Kurdistan's Referendum for Independence: Causes and Impacts
}

\author{
Zhao Changfeng, Otenia Temitayo \\ School of Political Science and International Studies, Central China Normal University, Wuhan, P. R. China
}

Email address:

zhchf2013@163.com (Zhao Changfeng), oteniatayo@yahoo.fr (O. Temitayo)

To cite this article:

Zhao Changfeng, Otenia Temitayo. 2017 Iraqi Kurdistan's Referendum for Independence: Causes and Impacts. Humanities and Social Sciences. Vol. 6, No. 2, 2018, pp. 59-67. doi: 10.11648/j.hss.20180602.13

Received: December 19, 2017; Accepted: January 20, 2018; Published: June 13, 2018

\begin{abstract}
On 20 November 2017, Iraqi Supreme Court has declared illegal the Iraqi Kurdistan referendum. This seems to put an end to the disagreement between Baghdad and Erbil and the long struggle of Iraqi Kurds to independence. The Kurdish issue has long haunted the Middle East, and the efforts of the Kurds to have a nation of their own have had a profound impact on the political landscape of the Middle East region. On September 25, 2017, the Iraqi Kurdish Autonomous Region held a referendum to decide whether to be independent or not. The results were opposed by the international community, especially by the neighboring countries of Iraq. This is mainly due to the fear of spillover effects on their own populations and the impact on the Middle East. This paper analyzes the causes and the consequences of the independence referendum on Iraqi Kurdish Autonomous Region relations with Iraq's central government, geopolitics in the Middle East and anti-terrorism war.
\end{abstract}

Keywords: Iraq, Kurds, Independence Referendum, Middle East

\section{Introduction}

The Kurdish issue mainly refers to the Kurdish people's aspiration for independence or autonomy and has a long past in the Middle East. The genesis of the problem can be linked to the era after the First World War. The ones to blame are the European colonial powers ${ }^{1}$. The Kurdish people, one of the oldest peoples in Western Asia, is the fourth largest nation in the Middle East, after the Arabs, the Turks, and the Persians. The Kurds share a common language and culture. Although, most of them practice Islam, there are other religious groups among the Kurds. They are mainly found in Turkey, Iran, Iraq, and Syria. The Kurdish nation is now the world's largest stateless nation ${ }^{2}$, and since the end of the First World War, the Kurds have carried out a series of actions for statehood. Although these attempts have failed, they have profoundly affected the political situation in the Middle East.

As the Seljuq Empire expanded, the enlarged Kurdistan

1 Jemal Nebez (2004), The Kurds History and Culture, London: Western Kurdistan Association Publications, p 61.

2 Jemal Nebez (2004), The Kurds History and Culture, London: Western Kurdistan Association Publications, p 7. was incorporated into the Turkish-Iranian world. Trapped in tensions between the Ottoman Empire and the Safavid Empire, the Kurds had to adapt to the new geopolitics ${ }^{3}$. The Kurds' disappointment resulting from the partition of the Ottoman Empire, combined with the policies of the newly emerged States towards minorities, has worsened the relations between Kurds and the latter. Northern Iraq is the first region to be the most impacted and to have been the stage for the Kurdish national independence movement. Three provinces of Northern Iraq constitute the Kurdish Autonomous Region. On 25th September 2017, the Iraqi Kurdish Autonomous Region (from now on referred to as the Iraqi Kurdistan) held a referendum on independence and people voted massively yes ${ }^{4}$. The United States, Turkey, and other countries made declarations that they would not acknowledge the referendum's results; Iraqi Kurdistan's referendum independence has become a widely debated topic within the international community and the Middle East region. What is the historical background of the Iraqi

\footnotetext{
3 Jordi Tejel (2009), Syria's Kurds History, politics and Society, New York: Routledge, $\mathrm{p} 68$.

4 Dong Manyuan (2017) "Kurdish issue and the situation of the Middle East", Guoji Wenti Yanjiu, No 4, p 42. (Translated by the authors)
} 
Kurdistan's referendum for independence? Does the referendum mean that the Iraqi Kurds will be able to achieve their dream of independent statehood? What is the reaction of the international community? What is the impact of such referendum on Iraqi Kurdistan, Iraq's domestic politics, the geopolitical landscape of the Middle East and the international War on terrorism? This article tries to analyze briefly these questions.

\section{Background of the Referendum: the "Independent Founding Dream" of Iraqi Kurds}

Since the foundation of Iraq, Iraqi Kurds and the Iraqi central government have had many tensions over oil resources and revenue distribution. In recent years, although the Iraqi Kurdistan and the central Government of Iraq held negotiations on issues such as autonomy and financial gains of the autonomous region, no substantive progress has been made. On 19th June 2017, the head of Iraqi Kurdish Autonomous Region's Department of Foreign Relations, Falah Mustafa Bakir declared that Iraqi Kurds, in recent years, have been dissatisfied with the inefficiency of their cooperation with the regime of Baghdad, prompting their decision to separate. As for the referendum's objective, Masoud Barzani, the President of Iraqi Kurdistan, said that the results would not lead to an immediate declaration of independence but should lay the basis for negotiations ${ }^{5}$. From his statement, the direct motive behind Iraqi Kurdistan's referendum is not the quest for independence, but the use of the spectrum of independence as a bargaining chip to get better concrete gains, thus laying a solid foundation for the later independent nation ${ }^{6}$. The Iraqi Kurdistan chooses to hold the independence referendum at that moment, because of historical reasons and realistic opportunities.

\subsection{The Historical Reasons for Iraqi Kurdistan's Referendum for Independence}

The historical background of the referendum for independence in Iraqi Kurdistan can be understood as the historical process of the autonomy's expansion of Iraqi Kurds. The Iraqi Kurds have much more autonomy compared to Kurds living in other countries. After the First World War, the Kurds in Iraq had been seeking autonomy and foundation of a sovereign state. Therefore, they created the Kurdish Democratic Party and the Kurdish Patriotic Union, two military armed groups, which were fighting Iraqi central government for greater autonomy. This referendum is not the first attempt of the Kurds to build

\footnotetext{
5 Iraqi Autonomous Region is disappointed by the ineffective talks with Bagdad, http://sputniknews.cn/politics/201706191022890797/, retrieved on $10^{\text {th }}$ October 2017.

6 Explaining the Restless Middle East,

http://paper.people.com.cn/rmrbhwb/html/2017-09/30/content_1808819.htm, retrieved on $11^{\text {th }}$ October 2017.
}

their own country. To understand the motives of the Kurds, one should return to the Sykes-Picot agreement of 1916, the 1920 Treaty of Sevres and the 1923 Treaty of Lausanne, whose primary objectives were to split the Ottoman Empire and to decide spheres of influences for the British and the French. The aim was to determine the extent to which the First World War victors would gain influence over parts of the Ottoman Empire's territory. The Ottoman Empire was a huge multi-ethnic State that spanned parts of Eastern Europe, Central and Western Asia, south-East Europe, North Africa and the Caucasus. It stood by Germany, Austria-Hungary's side during the First World War. They were defeated and had to cede parts of their territories and colonies. Kurds hoped to have their own country after the break-up of the Ottoman Empire, but they were deceived ${ }^{7}$. In fact, during the negotiations of the Sevres Treaty, the Kurds would decide their fate. However, the Treaty of Lausanne did not consider the Kurdish issue. The area they were living in, known as Kurdistan, was divided and merged into Turkey, Syria (French Mandate for Syria) and Iraq (British Mandate for Irak). Those territories inhabited by Kurds added to the Iranian Kurdistan can be referred to as enlarged Kurdistan. A part fell into the Soviet Union's territory, however, since the dissolution, it is currently integrated to Armenia and Azerbaidjan ${ }^{8}$.

Many uprisings led by the Kurds took place after the partition of the Ottoman Empire. In Iraq, between 1919 and 1922, they revolted two times, led by Mahmud Barzanji, and established the Kingdom of Kurdistan. The kingdom was dissolved by the British in $1924^{9}$. From 1927 to 1930 , the Turkish Kurds established the Republic of Ararat ${ }^{10}$. In fact, Turkey regards Kurdish nationalism and the desire of a Kurdish state as a threat to the principle of indivisibility of Turkey's territory (national unity) ${ }^{11}$. As a result, the Turkish government implemented policies of assimilation for Turkish Kurds. The Kurds were considered as being part of the Turkish people and were referred as Turks of the mountains. Ismael Besikci, in his book, "Mahkemelerin Actigi yol" (Paths opened by courts), provided a very clear definition of the concept of the Turkish national unity, by quoting the Attorney General, Cemalettin Celik: "Citizens of the Turkish Republic are called the Turks. In Turkey, there is no other nation other than the Turkish nation, no other language other than the Turkish language. Existence of a nation other than the Turks, a language other than Turkish is unacceptable. All people dependent on the Turkish state are Turks... To say that there is a nation other than Turks and a language other than

7 Carole A. O'Leary (2002), THE KURDS OF IRAQ: RECENT HISTORY, FUTURE PROSPECTS, Middle East Review of International Affairs, Vol. 6, No. 4.

8 Jemal Nebez (2004), The Kurds History and Culture, London: Western Kurdistan Association Publications, p 7.

9 Jemal Nebez (2004), The Kurds History and Culture, London: Western Kurdistan Association Publications, p 36.

10 Kemal Kirisci, Gareth Winrow (1997), The Kurdish Question and Turkey:an example of a trans-state ethnic conflict, Routledge, p 101.

11 Ceng Sagnic, Mountain Turks: State ideology and the Kurds in Turkey, Information, Society and Justice, Volume 3 No. 2, July 2010. 
Turkish and support this language and culture is a crime." 12 Iran has also experienced several Iranian Kurdish uprisings, and in 1946 the Iranian Kurds established the Republic of Mahabad ${ }^{13}$. The republic lasted less than a year. Yacin Dusman $^{14}$ (2014) wrote that Syrian Kurds were oppressed and discriminated. The Kurds were oppressed because at that time, the newly independent states' authorities feared that their minorities could be used by foreign countries against them ${ }^{15}$. In Iraq, the history of Kurds' autonomy can be divided into three periods since Iraq's independence in $1958^{16}$ :

From 1958 to 1991: After Iraq's independence, the Kurdish Democratic Party proposed a series of national autonomous programs, but was strongly opposed by the central government. Subsequently, the Kurdish Democratic Party and the Kurdish Patriotic Alliance allied to fight the Iraqi central government for the quest of autonomy. Despite repeated military crackdowns by the central government, Iraqi Kurds grew in strength. The Iraqi central government had to make concessions to formally recognize the existence and the rights of the Kurdish people as well as their rights of participation in the national political process.

From 1991 to 2003: After the first Gulf War, the United States set up a no-fly zone in the Kurdish areas of northern Iraq, guaranteeing, to some extent, the de facto independence of Iraqi Kurds ' political power, and the elections in Iraqi Kurdistan in 1992. After the creation of Barzani-led Kurdish Democratic Party and Talabani-led Kurdish Patriotic Union, the pace of autonomy has been accelerating.

From 2003 to 2017: After the overthrow of Saddam Hussein's regime in 2003, the authority of Iraqi central Government was further attenuated and Iraq's domestic politics were further fragmented, largely expanding the autonomy of Iraqi Kurds. The new Iraqi constitution of 2005 granted a greater autonomy to the Iraqi Kurdistan region. In 2014, Islamic State's extremist groups were progressing in Northern and Western Iraq and in order to confront them, the Iraqi central government had to cooperate with the Iraq's Kurdish autonomous region. At the same time, the autonomous region has received military, financial and material support from the United States and Saudi Arabia in the process of fighting against the Islamic State. The Iraqi Kurds played a very important role in the war against terrorism. In addition, the gradual expansion of the current Iraqi Kurd-controlled areas over the past 14 years and the inclusion of the oil-rich Kirkuk have laid the foundation for the further expansion of their autonomy.

12 Quoted from Ceng Sagnic, Mountain Turks: State ideology and the Kurds in Turkey, Information, Society and Justice, Volume 3 No. 2, July 2010: pp 127-134. 13 David McDowall (2007), A modern History of the Kurds, New York: I. B. Taurus, pp 231-248.

14 Yacin Dusman (2014), Remembering the "forgotten" Kurds in Syria, http://www.e-ir.info/2014/10/31/remembering-the-forgotten-kurds-in-syria/, retrieved on $7^{\text {th }}$ November 2017

15 Jordi Tejel (2009), Syria's Kurds History, politics and Society, New York: Routledge, $\mathrm{p} 4$.

16 Liu Sherong (2016) "Reasons for Iraqi Kurds' high degree of autonomy and perspectives", "Xin Xibu", No, p 104.

\subsection{Realistic Opportunities for Independence Referendum and the Rise of the Islamic State}

To some extent, the rise of the Islamic State provided a real opportunity for an independent referendum in Iraqi Kurdistan. The rise of the Islamic State in 2014, the brutal repression of ethnic minorities exacerbated the Kurds ' sense of crisis. Masoud Barzani said that only independence could ensure the security of Iraqi Kurds ${ }^{17}$. For Iraqi Kurdistan, it was the right time, compared to previous attempts, to seek for independence. Firstly, from a political and economic perspective: after the fall of Saddam's government, Iraq's domestic political environment experienced fragmentation, and Iraqi central government's control decreased. The rise of the Islamic State has led to a further decline of the Iraqi central government's credibility. However, the status of Iraqi Kurds has risen sharply as they play an important role in the war against the Islamic State. Moreover, the advantageous geographical location and excellent natural conditions of Iraqi Kurdistan make it Iraq's natural "oil reservoir" and "granary." The oil reserves of the Kirkuk ${ }^{18}$ region account for $40 \%$ of the total oil reserves of Iraq, and it lays a solid economic foundation for Iraqi Kurdistan's quest for independence.

Secondly, from a regional perspective: in recent years, the fact that the Islamic State has stirred confusion in the Middle East, has provided an opportunity for a referendum for Iraqi Kurdistan's independence. The various riots and terrorist attacks in the Middle East by the Islamic State have greatly endangered people's safety, and to maintain regional stability and security, Middle East countries have invested a lot in human, material and financial resources to fight back. In the meantime, Iraqi Kurdistan has received material assistance from around the world and has been growing in strength in the fight against the Islamic State. The Islamic State's rise had also exacerbated the long-standing contradictions in the Middle East, changing the geopolitical landscape. For instance, the central regimes in Iraq and Syria have been severely weakened by the friction between the Sunni and Shia factions respectively represented by Saudi Arabia and Iran. All that chaos in the Middle East has distracted the attention of Middle East countries, thus providing a favorable external environment for the rise of the Iraqi Kurdish people.

Finally, from the international opinion's perspective: in summer 2014, the rise of the Islamic State, the brutal persecution, and repression of Kurds and other ethnic groups in Iraq sparked concerns from the international community. At a critical juncture, Iraqi Kurdish militants, backed by the international community, resisted to the Islamic State's offensive and contained its expansion. Significant progress has been made in the fight against the Islamic State and in the process, Iraqi Kurds have gained an important role to play

17 "Barzani to Kurds: Vote in referendum to secure future", http://www.aljazeera.com/news/2017/09/barzani-kurds-vote-referendum-securefuture-170924142342480.html, retrieved on $12^{\text {th }}$ October 2017.

18 It has to be noted that Kirkuk region is a disputed region between Iraqi Kurdistan and Iraq's central government. 
and have also gained the understanding and recognition of the international community in their contribution against terrorism.

\section{Response of the International Community to the Independent Referendum}

On 27th September 2017, the Iraqi Kurdistan media, Rudaw News Network, released the referendum's results. The votes for independence accounted for $92.73 \%$. From this result, it can be seen that the Iraqi Kurds have a deep public opinion over the quest for independence. It can be said that referendum's results had helped to save Iraqi Kurdistan political leaders' face and allowed Masoud Barzani and other Iraqi Kurdistan's politicians to be seen as "national heroes" in the eyes of Iraqi Kurds. Did the results mean that the Iraqi Kurds could realize their dream of having their own state? Have the Iraqi Kurds won? Not really. The results have sparked hostile reactions from the Iraqi central government and also from the neighboring countries. Iran and Turkey have taken tough measures in protests to the independence referendum. An analysis of reactions from the international community allows to distinguish three camps: most countries and international organizations such as the United Nations form the opposition camp, Israel has a supportive attitude, and Russia's stance is ambiguous.

\subsection{Opposing Parties: the Case of Four Middle East's Countries (Syria, Turkey, Iran, and Irak), China, the United States and the United Nations}

Iraqi Kurdistan's referendum for independence is linked to the unity and partition of Iraq. As the central government in Iraq strongly opposed the independence referendum in Iraqi Kurdistan, the authorities issued a warning that the independence referendum is a "strategic and historic mistake." Iraq's Prime Minister Haider al-Abadi, on 27th September, called on Iraqi Kurdish authorities to cancel the referendum results ${ }^{19}$.

Turkey, Iran, and Syria had also expressed strong opposition to the Iraqi Kurdistan independence referendum, fearing colossal spillover effects over separatist tendencies in their respective countries. Turkey has long regarded the government of the Iraqi Kurdistan as a key partner, and the Iraqi Kurdistan has trade and political ties with Turkey. However, since the announcement of the independence referendum, Turkey has quickly shifted its stance and expressed its strong opposition to the independence referendum, fearing that the Iraqi Kurds ' initiative to pursue independence would have spillover effects over its own Kurdish population. Turkish President Recep Tayyip Erdogan said that the Iraqi Kurdistan would pay the price for an

19 Explaining the Restless Middle East,

http://paper.people.com.cn/rmrbhwb/html/2017-09/30/content_1808819.htm, retrieved on $15^{\text {th }}$ October 2017. independence referendum that is widely opposed by the international community ${ }^{20}$. Turkey's change of attitude towards Iraqi Kurds is linked to its domestic politics. Many Kurds live in Turkey, and the Turkish government fears that an independent Kurdish State by its borders will exacerbate its own Kurdish population's separatist tendencies in its territory ${ }^{21}$.

Also concerned by the spillover effects of the Iraqi Kurdistan's independence referendum, Iran and Syria voiced strong opposition to the referendum. The Iranian government fears that an independence referendum in the Iraqi Kurdistan would exacerbate separatist tendencies and endanger its national security and territorial integrity. The Iranian President, Hassan Rouhani, during a meeting with Turkish President Recep Tayyip Erdogan, said that Iraq is an independent sovereign state and that Iran would not accept any geographical changes ${ }^{22}$. The leaders of the Syrian Kurdish militant group said that the Iraqi Kurdistan referendum for independence could bolster Syrian Kurds to negotiate with the Syrian government over the issue of autonomy $^{23}$. That declaration from Syrian Kurdish militant group's leaders has made the Syrian government concerned about an independent Iraqi Kurdistan's impact on its Kurdish population. Since March 2016, the Syrian Kurdistan is de facto autonomous region, known as Rojava and seen by its supporters as a foundation for a federalized Syria ${ }^{24}$. If Iraqi Kurdistan is independent, the spillover effect would exacerbate the separatist tendencies of Kurdish armed groups in Syria and would further weaken the Syrian political landscape. Therefore, the Syrian central government strongly opposed the independence referendum.

As a permanent member of the Security Council, China had voiced its opposition to the independence referendum of Iraqi Kurdistan. Chinese Foreign Ministry spokesperson declared that the independence referendum undermines the national unity and territorial integrity of Iraq and violates the Charter of the United Nations and the basic principles of international law $^{25}$. The referendum undermines the stability

20 "Turkey's Erdogan says Iraqi Kurdish authorities "will pay price" for vote", , http://www.reuters.com/article/us-mideast-crisis-kurds-referendum-turke/turkeyserdogan-says-iraqi-kurdish-authorities-will-pay-price-for-vote-

idUSKCN1C50FX, retrieved on $3^{\text {rd }}$ October 2017.

21 "Iraqi Kurds must give up on independence or go hungry - Erdogan", http://www.bbc.com/news/world-middle-east-41398199, retrieved on $7^{\text {th }}$ October 2017.

22 "Erdogan, Rouhani united in opposition to Kurdish state", http://www.aljazeera.com/news/2017/10/erdogan-rouhani-united-oppositionkurdish-state-171004124507138.html, retrieved on $7^{\text {th }}$ October 2017.

23 "Iraq Kurdish vote may benefit Syrian Kurds, say their leaders", https://www.reuters.com/article/us-mideast-crisis-kurds-referendum-syria/iraqkurdish-vote-may-benefit-syrian-kurds-say-their-leaders-idUSKCN1C22RX, retrieved on $7^{\text {th }}$ October 2017.

24 Analysis: This is a new Syria, not a new Kurdistan, Middle East Eye, http://middleeasteye.net/news/analysis-kurds-syria-rojava-1925945786, retrieved on $15^{\text {th }}$ November 2017.

25 "On $27^{\text {th }}$ September 2017, Foreign Ministry's spokesman Lu Kang held a press conference",

http://www.fmprc.gov.cn/web/fyrbt_673021/t1497487.shtml, retrieved on $5^{\text {th }}$ October 2017. 
of the political situation in the Middle East. Political stability is crucial for China to implement the "One Belt One Road" initiative. The negative spillover effect of the Iraqi Kurdistan independence referendum would exacerbate the separatist tendencies and destabilize the Middle East. Therefore, China calls on all the concerned parties to resolve their differences through dialogue and consultation and to jointly safeguard peace and stability of Iraq and the region.

The United States has long supported the Kurdish people in the Middle East for strategic reasons and has funded and provided weapons to the Iraqi Kurds in their fight against the Islamic State. The United States changed its attitude when Iraqi Kurdistan developed, in the process of counterterrorism, an independentist behavior. American opposition to the referendum is influenced by its interests in the Middle East. The rapid rise of the Islamic State, using Syria and Iraq as their bases, has formed the mainstream of international terrorism, threatening not only the regime in Syria but also posing a challenge to regional and global security. In the fight against Islamic State's extremist groups, Iraqi Kurdish armed groups played an important role with the support of the international community. Although Masoud Barzani said that the referendum would not affect the fight against the Islamic State ${ }^{26}$, the time was not favorable. The referendum for independence and events linked to it might distract Iraqi Kurds in their fight against the terrorists. The Kurds play a too important role ${ }^{27}$. Also, the opposition of the international community to the referendum might lead to the reduction of support (material and financial support). A spokesman for the US-led anti-terrorist coalition said that Iraqi Kurdistan's referendum for independence had reduced the attention over the Islamic State, allowing the latter to regain in strength ${ }^{28}$. The United States is concerned that the referendum for independence would divert attention from critical issues, such as the fight against the Islamic State and that would affect the Middle East's stability and anti-terrorism process. Hence, U.S. Secretary of State, Rex Tillerson, on 29th September, stated that: "the vote and the results lack legitimacy, and we continue to support a united, the federal, democratic and prosperous Iraq" 29 .

As the largest and most authoritative inter-governmental and international organization in the world, the United Nations has publicly criticized the independence referendum of Iraqi Kurdistan. The U.N. Security Council has warned that a referendum for independence in Iraqi Kurdistan would have devastating effects ${ }^{30}$. On 25 th September, the Secretary-

26 "Kurdish leader Barzani: Independence will not disrupt fight against ISIL", http://www.aljazeera.com/news/2017/09/kurdish-leader-barzani-independencedisrupt-fight-isil-170923085108172.html, retrieved on $10^{\text {th }}$ October 2017.

27 The Syrian Kurds are also fighting the Islamic State in Syria.

28 "Loss of focus in fighting Islamic State after Kurdish referendum: coalition spokesman", https://www.reuters.com/article/us-mideast-crisis-kurds-

pentagon/loss-of-focus-in-fighting-islamic-state-after-kurdish-referendumcoalition-spokesman-idUSKCN1C32LJ, retrieved on $7^{\text {th }}$ October 2017.

29 "Iraqi Kurdistan Regional Government's Referendum",

https://www.state.gov/secretary/remarks/2017/09/274522.htm, retrieved on $3^{\text {rd }}$

October 2017.

30 "Iraqi Kurdish referendum: UN warns of 'destabilizing impact",
General of the United Nations, Antonio Guterres, said that he respected the sovereignty, territorial integrity and unity of Iraq and believed that Iraqi Central Government and the Iraqi Kurdistan autonomous region government region should resolve their differences through constructive dialogue ${ }^{31}$.

\subsection{Supportive Party: Israel}

After Iraqi Kurds announced their intention to organize the referendum, Israel was the only country to publicly support them. Israel's supportive stance has attracted much attention in the almost-one-sided opposition. Israeli Prime Minister, Benjamin Netanyahu said that Israel supports the Kurdish people in their efforts to establish an independent state through legal means ${ }^{32}$.

Israel's position over the referendum can be understood from two perspectives: history and geopolitical facts. Firstly, because the Jewish people had experienced a similar historical misfortune with the Kurds, Israel expressed its sympathy and its understanding of the Kurds' dream of independence and statehood. The Jews have been deported and remained stateless for a long time before successfully having their state again. The Kurds are now living in four different countries. Both people have experienced the pain and trauma caused by war. Both are minorities in the middle of the three major peoples of the Middle East region: Arabs, Persians, and Turks, therefore the Israelis sympathized with the Kurds in their efforts to build an independent nation. Secondly, from a realistic geopolitical perspective, Israel wants to use the opportunity of an independent Kurdistan to improve its national security environment. The conflict between Jews and Arabs is a long-standing one, and Israel is surrounded by Arab states. Therefore, State security is Israel's priority. An independent Iraqi Kurdistan would not only divert Arab nations' attention from Israel but also weaken them, relieving the pressure on Israel's security. Also, an independent Kurdistan would be a valuable ally in the region.

\subsection{Ambiguous Party: Russia}

Russian Foreign Minister Sergei Lavrov said that Russia respects Iraq's sovereignty, unity, and territorial integrity. However, on the 27th September, a Russian Ministry of Foreign affairs' spokesman said that Russia respected the Kurdish national aspirations and suggested that the Iraqi central government resolves the disputes with the Iraqi Kurdish autonomous regional government through a constructive dialogue ${ }^{33}$. This seems contradictory and might

http://www.bbc.com/news/world-middle-east-41359361, retrieved on $7^{\text {th }}$ October 2017.

31 "UN chief voices concern over 'potentially destabilizing effects' of Kurdish referendum",

http://www.un.org/apps/news/story.asp?NewsID=57731\#.WdL2noUY-wY, retrieved on $4^{\text {th }}$ October 2017.

32 Lorenzo Kamel:"Kurdish independence vote: A historical perspective", http://www.aljazeera.com/indepth/opinion/kurdish-independence-vote-historicalperspective-170922093133193.html, retrieved on $4^{\text {th }}$ October 2017.

33 "Comment by the Information and Press Department on the referendum in 
accrue from Russia's interests in the region. On the one hand, Russia, as a permanent member of the Security Council, adheres to the principles of the Charter of the United Nations and international law principle of territorial integrity but at the same time, it is opposed to what the international community stands for on Iraqi Kurdistan's referendum. It is interesting to note that Syria provides Russia its only and strategic access to the Mediterranean Sea, and Moscow is not willing to lose it. That is the Russian naval base of Tartus. Supporting Iraqi Kurds might compromise Russian presence in Syria, because of the Syrian Government's fear of what can happen next if Iraqi Kurdistan is internationally recognized as an independent state. So, Russia respects the territorial integrity of Iraq. On the other hand, by expressing understanding and support for the efforts of the Kurds in Iraq, Russia hopes to expand its influence and voice in the Middle East and to develop relations with the Kurdish people.

\section{The Consequences of Iraqi Kurdistan's Referendum}

The diverse reactions from the international community and the following events resulting from the Iraqi Kurds' selfdetermination's project demonstrated that the referendum did not go well as planned. After the independence referendum, Iraqi Kurdistan faced enormous economic development, social and security pressure.

\subsection{The Referendum That Would Change the Deal in Iraq}

Iraqi Kurdistan's referendum for independence has undermined Iraq's national unity, pushing the Iraq's central government to take tough countermeasures. Iraq is a member of the United Nations and its national sovereignty, and territorial integrity is guaranteed by the Charter of the United Nations and international law. The referendum for independence in Iraqi Kurdistan, which is meant to separate Iraqi Kurdistan from Iraq, questioned Iraq's national unity and territorial integrity. Iraq's central government has repeatedly voiced opposition to the independence referendum. For Baghdad, the referendum is unconstitutional, and the central government is working with its neighbors, Turkey and Iran, to gradually implement sanctions against Iraqi Kurdistan. In response to the results of the Kurdish referendum, the Iraq's Minister of Defense said that it would cooperate with Iran and Turkey to control the borders of Iraqi Kurdistan (including some oil-producing areas in the Kurdish-controlled Kirkuk province) ${ }^{34}$. Also, Iran has declared an air embargo on flights between Iran and

Iraqi Kurdistan", http://www.mid.ru/en/web/guest/kommentarii_predstavitelya//asset_publisher/MCZ7HQuMdqBY/content/id/2875494, retrieved on $4^{\text {th }}$ October 2017.

34 "Iraqi forces plan takeover of Kurdish region's borders", http://www.aljazeera.com/news/2017/09/iraqi-forces-plan-takeover-kurdishregion-borders-170929184841868.html, retrieved on $4^{\text {th }}$ October 2017.
Iraqi Kurdistan ${ }^{35}$.

Secondly, the referendum could lead to the intensification of internal contradictions in Iraq, affecting the stability of the Iraqi political situation. After the overthrow of Saddam Hussein's regime, Iraq's factions were ambivalent: the main interest of the Sunni faction was to regain control of state power and preserve the territorial integrity of the country. The Shia faction wanted to consolidate State power, and the core interests of Iraqi Kurds were to uphold their degree of autonomy and even found a State. It can be said that the interests of Iraq's different factions are conflicting. First of all, the Sunni faction's desire of regaining the control of State power and Shia faction's desire of consolidating State power created contradictions. Moreover, the Sunni faction in their process of maintaining the national territorial integrity and the Iraqi Kurds in their pursuit of independence clashed. Another point was that Iraq's Shia faction needed oil resources and revenues to consolidate State power and it happened that Iraqi Kurds wanted more control over oil resources and financial gains. This situation resulted in another clash with the Shia faction. Iraqi Kurdistan's referendum for independence had further intensified the conflicts among factions.

An independent Iraqi Kurdistan would contradict the Iraqi's Sunnis in their plan to preserve the territorial integrity of Iraq. That would lead to a conflict between the two factions. Secondly, if independence cannot be achieved, Iraqi Kurdistan's political leaders might want more autonomy (including control over oil-rich Kirkuk). Because of the oil resources, Iraqi Shias and Iraqi Kurds might fight over Kirkuk. Iraqi Kurdistan is rich in mineral resources. It can be noted that the geographical map of natural resources is merged with the geopolitical map of conflict: where there is wealth, conflict is not far away. Who controls the resources? How to share the revenues generated from the exploitation of those mineral resources? According to Dmitri Marinchenko, Iraqi Kurdistan has $3 \%$ of the world's oil reserves and onethird of Iraq's reserves ${ }^{36}$. Oil can also be found in Jazira (Syrian Kurdistan), Batman (Turkish Kurdistan) as well as in $\mathrm{Iran}^{37}$. No need to say that all the four countries will not give up on their respective "Kurdistan".

Therefore, Iraq's central government and its Parliament strongly opposed the referendum. Even if a unilateral declaration of independence was made; without a solid foundation of international law and due to the combined economic, political and military threats of Iraq's neighboring countries, as well as the pressure of international public opinion, it will be be hard for Iraqi Kurdistan to survive and develop as an independent nation.

35 "Iraqi Kurds under pressure after independence vote", http://www.aljazeera.com/news/2017/09/iraqi-kurds-pressure-independence-vote170927095905287.html, retrieved on $4^{\text {th }}$ October 2017.

36 Le Kurdistan dispose d'environ 3\% des réserves mondiales de pétrole, http://fr.sputniknews.com/international/201709261033225544-kurdistan-reservespetrole/, retrieved on 15th November 2017.

37 Dr Jawad Mella (2005), Kurdistan and the Kurds: A divided homeland and a nation without State, London: Western Kurdistan Associations Publications, p 23. 


\subsection{The Fear of Turkey and Iran}

Before the referendum, Turkey used to keep close economic ties with Iraqi Kurdistan and was the main oil export channel for Iraqi Kurdistan. The economic development of Iraqi Kurdistan relies on abundant oil resources and that oil is exported mainly through Iran and Turkey to the world oil market. However, those countries strongly opposed Iraqi Kurdistan's referendum for independence and joined hands together with Iraq to restrict the political activities of Iraqi Kurds through economic means, such as imposing an embargo on oil exportation from Iraqi Kurdistan and halting or reducing trade with the autonomous region. After the referendum, Turkey imposed a ban on oil from the autonomous region, causing economic losses to $\mathrm{Erbil}^{38}$. Iran reduced water supplies to Iraqi Kurdinhabited areas. Aljazeera reported the statements of Iraqi Kurdish farmers living along the border with Iran that it was a punishment. If water resources lack over a long term, it would negatively impact on agriculture in the autonomous region, resulting in enormous pressure on social stability. Furthermore, an Iranian army's spokesman announced that the Iranian and Iraqi central government's forces would conduct joint military exercises along the borders between the two countries ${ }^{39}$. Following his declaration, Iranian and Iraqi central government's troops held a joint military exercise near the border between the two countries, Iraqi security forces stationed in the disputed areas controlled by the Kurds. On 26th September, Turkish and Iraqi armed forces held joint military exercises along the border areas of both countries $^{40}$. On 27th September, the Turkish Air Force's warplanes targeted launched strikes on Kurdistan Workers' Party militants in northern Iraq, killing 13 members of the armed group. The "united front" involving Iran, Iraq, and Turkey put Iraqi Kurds under a lot of pressure. The sanctions imposed by Turkey and Iran posed enormous challenges and threats to the economic development of Iraqi Kurdistan and the freedom and security of Kurds.

Iran, Iraq, Turkey, and Syria have a firm will to protect the integrity of their respective territories. The creation of an independent Kurdish entity anywhere in enlarged Kurdistan would threaten the territorial integrity of those countries, sparking a new wave of separatist sentiments among the other Kurds and other ethnicities. All four countries are multi-ethnic and have multi-faith societies. Iraq may experience tensions between Sunni and Shia populations leading to the creation of Shia and Sunni states. Same threats of partition are great concerns for Iran, Syria, and Turkey with their minorities.

38 Erbil is the capital city of the Iraq's Kurdish autonomous region 39 "Iran and Iraq to hold joint border drills", http://www.aljazeera.com/news/2017/09/iran-iraq-hold-joint-border-drills170930144038863.html, retrieved on $8^{\text {th }}$ October 2017.

40 "Iraq, Turkey forces in joint drills after Kurdish vote",

http://www.aljazeera.com/news/2017/09/iraq-turkey-forces-joint-drills-kurdishvote-170926090905754.html, retrieved on $10^{\text {th }}$ October 2017.

\subsection{The Choice of the International Community}

The international community's opposition to Kurdistan's aspirations for independence did not help matters. Any major political development that occurs in the international community needs a certain degree of international legitimacy, especially on such important issues that involve national independence. Masoud Barzani believed that the referendum was an inherent right of the Kurds to pursue national selfdetermination $^{41}$. This shows that the basic principle of international law sought by Iraqi Kurdistan through the referendum is the "right to national self-determination." Thus, the referendum's conformity with the principle of national self-determination is an important criterion for knowing whether there is an international legitimacy or not. The principle of national self-determination refers to the right of the oppressed people under foreign servitude and colonial domination to decide their fate, free themselves from colonial rule and found a state. Therefore, an important prerequisite for the principle of self-determination is that people aspiring for it must be enslaved or colonized by foreign countries, hence they have the right to seek for freedom and independence ${ }^{42}$. In Iraqi Kurdistan's case, the Iraqi Kurds are not enslaved or colonized by any foreign entity. Iraqi Kurdistan was fully part of Iraq after the partition of the Ottoman Empire and also after Iraq's independence. Furthermore, Iraqi Kurdistan region enjoys a high degree of autonomy, so the referendum is not conformed to the principle of self-determination. From that perspective, Iraqi Kurdistan's referendum for independence can be seen as a political move aimed at separating the region from the rest of Iraq, thus weakening Iraq's national unity and territorial integrity and challenging the authority of international law. Therefore, it was vehemently opposed by the international community.

Furthermore, the rapid rise of the Islamic State, using Syria and Iraq as their base, has formed the mainstream of international terrorism, threatening not only the regime in Syria but also posing a challenge to regional and global security. In the fight against Islamic State's extremist groups, Iraqi Kurdish armed groups played a significant role with the support of the international community. In such a critical moment, their full attention was needed on the fight against the terrorists. The referendum for independence and events linked to it might distract Iraqi Kurds. They play a significant role, and the war against the terrorists is not yet fully completed.

A dilemma arises on how to balance the right of people to self-determination and the sovereignty of established States in the context of the Kurdish problem when compared to the case of Kosovo. Although Serbia was a sovereign state, the Albanians of Kosovo got support from the international community and founded their own state. If in the Kosovo's case, only one established and sovereign State (Serbia) was

\footnotetext{
41 Christopher M. Blanchard:” Kurds in Iraq Propose Controversial Referendum on Independence", https://fas.org/sgp/crs/mideast/IN10758.pdf, retrieved on $7^{\text {th }}$ October 2017

42 Wang Tieya (1981), Internaltional Law, Law Publishing House, p 61
} 
involved, four States are concerned by the Kurdish issue and they are less likely to lose their Kurdistan parts. Moreover, the Middle East is one of the hot spots of geopolitics: the Israeli-Palestinian issue; Syria's crisis; terrorism. The stability of the region is very fragile, and the situation will worsen if countries are divided. The referendum in Iraqi Kurdistan is not only a matter of the Kurds, but also a crucial question of what the international community wants the world to be: a more fractioned geopolitical map or a quest for stability and peace in the current geopolitical map? Is the international community ready to handle the chaotic outcome of an independent Iraqi Kurdistan? An independent Iraqi Kurdistan might not only strengthen the sense of separatism in the Middle East, but also help spread it in other parts of the world. It is not a secret that many countries are confronted by separatist movements. Separatist activities are experienced by African countries: Cabinda (Angola), Biafra (Nigeria), Northwest and Southwest regions (Cameroon), Tuareg issues (Mali). Europe has also not been spared by separatist sentiments, such as in France (Corsica), Spain (Catalonia), the United Kingdom (Scotland) and so on. Neither has the Asian continent been spared.

Madrid's reaction to the Catalan referendum of $1^{\text {st }}$ October 2017 shows that countries are not willing to let go even one centimeter of their territory ${ }^{43}$. Other examples can be found in the tensions between French central government and some separatist movements. So can countries support separatism in other parts of the world without fearing a boomerang effect or while fighting it too on their own soil? Such a behavior would be damageable for the image of those countries and their relations with other countries.

Iraqi Kurdistan, aware of the danger of conflict escalation with Baghdad and the hostility of neighboring countries, proposed to freeze the results of the referendum. A few days later, Masoud Barzani revealed his intention to step down from the presidency of Iraqi Kurdistan. He effectively stepped down on 1st November 2017. On 20th November 2017, Iraq's Supreme Court declared Iraqi Kurdistan's referendum for independence unconstitutional. Have the Iraqi Kurds won? It seems that no. But the outcome of the negotiations between Erbil and Baghdad is an important step as it would determine the future of Iraqi Kurds, Iraq and the Middle East's political stability. One point is clear: neither Iraq nor its three neighbors wish for a partition. Moreover, the fear that their Kurdish populations could revolt would prompt Turkey, Syria, and Iran to take more stringent steps to contain them. Such scenario would comfort the Kurds ' sense of self-determination, stirring up more uprisings and worsening the current situation.

\section{Conclusion}

Although the United Nations Charter recognizes the people's right to self-determination, it has always brought a

43 Madrid has imposed a direct rule over Catalonia after the Catalan referendum of independence of $1^{\text {st }}$ October 2017 dilemma and endless debate in international relations. This dilemma lies in the conflict of interests between those who wish to free themselves and those who do not wish to lose parts of the territory. Who is right? Who is wrong? The answer depends on different considerations, such as historical facts, academic beliefs, geopolitical stakes, and so on. If external forces get involved, the problem becomes more complicated. The latter often decide to support the parties with whom they have interests to protect or where they can get better gains. As far as the Kurdish issue is concerned, the international community is more interested in preserving peace in the Middle East and an intact Iraq is an essential part of that peace. Why? Because supporting Iraqi Kurds would have disastrous effects in the region, not to mention the chaos it will bring in the fight against terrorism.

As the fourth largest ethnic group in the Middle East, the Kurds' quest for independence has never ceased. However, it has been strongly opposed by the international community because of its lack of a solid foundation on international law and the negative spillover risks it poses to the entire region. Thus, the Iraqi Kurds are unlikely to realize the dream of an independent statehood in the near future. Given Iraq's complex domestic politics and the geopolitical realities in the Middle East, a constructive dialogue and negotiations between the Iraq's central government and Iraqi Kurdistan to reconcile differences and rationalization of interests might provide an amicable solution to the Kurdish issue.

\section{References}

[1] On $27^{\text {th }}$ September 2017, Foreign Ministry's spokesman Lu Kang held a press conference

[2] "Barzani to Kurds: Vote in referendum to secure future", http://www.aljazeera.com/, retrieved on $12^{\text {th }}$ October 2017.

[3] "Comment by the Information and Press Department on the referendum in Iraqi Kurdistan", http://www.mid.ru/, retrieved on $4^{\text {th }}$ October 2017.

[4] "Erdogan, Rouhani united in opposition to Kurdish state", http://www.aljazeera.com/, retrieved on $7^{\text {th }}$ October 2017.

[5] "Iran and Iraq to hold joint border drills", http://www.aljazeera.com/, retrieved on $8^{\text {th }}$ October 2017.

[6] "Iraq Kurdish vote may benefit Syrian Kurds, say their leaders", https://www.reuters.com/, retrieved on $7^{\text {th }}$ October 2017.

[7] "Iraq, Turkey forces in joint drills after Kurdish vote", http://www.aljazeera.com/, retrieved on $10^{\text {th }}$ October 2017.

[8] "Iraqi forces plan takeover of Kurdish region's borders", http://www.aljazeera.com/, retrieved on $4^{\text {th }}$ October 2017.

[9] "Iraqi Kurdish referendum: UN warns of 'destabilizing impact"”, http://www.bbc.com/, retrieved on $7^{\text {th }}$ October 2017.

[10] "Iraqi Kurdistan Regional Government's Referendum", https://www.state.gov/, retrieved on $3^{\text {rd }}$ October 2017. 
[11] "Iraqi Kurds must give up on independence or go hungry Erdogan", http://www.bbc.com/, retrieved on $7^{\text {th }}$ October 2017.

[12] "Iraqi Kurds under pressure after independence vote", http://www.aljazeera.com/, retrieved on $4^{\text {th }}$ October 2017.

[13] "Kurdish leader Barzani: Independence will not disrupt fight against ISIL", http://www.aljazeera.com/, retrieved on $10^{\text {th }}$ October 2017.

[14] "Kurdish leader Barzani: Independence will not disrupt fight against ISIL", http://www.aljazeera.com/, retrieved on $10^{\text {th }}$ October 2017.

[15] "Loss of focus in fighting Islamic State after Kurdish referendum: coalition spokesman", https://www.reuters.com/, retrieved on $7^{\text {th }}$ October 2017.

[16] "Turkey's Erdogan says Iraqi Kurdish authorities "will pay price" for vote", http://www.reuters.com/, retrieved on $3^{\text {rd }}$ October 2017.

[17] "UN chief voices concern over 'potentially destabilizing effects' of Kurdish referendum", http://www.un.org/, retrieved on $4^{\text {th }}$ October 2017.

[18] Explaining the Restless Middle East, http://paper.people.com.cn/rmrbhwb/html/201709/30/content_1808819.htm, retrieved on $11^{\text {th }}$ October 2017.

[19] Explaining the Restless Middle East, $\mathrm{http} / / /$ paper.people.com.cn/rmrbhwb/html/201709/30/content_1808819.htm, retrieved on $15^{\text {th }}$ October 2017.

[20] Analysis: This is a new Syria, not a new Kurdistan, Middle East Eye, http://middleeasteye.net/, retrived on $15^{\text {th }}$ November 2017.

[21] Carole A. O'Leary (2002), THE KURDS OF IRAQ: RECENT HISTORY, FUTURE PROSPECTS, Middle East Review of International Affairs, Vol. 6, No. 4.

[22] Ceng Sagnic (2010), Mountain Turks: State ideology and the Kurds in Turkey, Information, Society and Justice, Volume 3 No. 2, pp 127-134.
[23] Christopher M. Blanchard (2017), "Kurds in Iraq Propose Controversial Referendum on Independence", Congressional Research Service Reports on the Middle East and the Arab World, https://fas.org/, retrieved on $7^{\text {th }}$ October 2017.

[24] David McDowall (2007), A modern History of the Kurds, New York: I. B. Taurus, pp 231-248.

[25] Dr Jawad Mella (2005), Kurdistan and the Kurds: A divided homeland and a nation without State, London: Western Kurdistan Associations Publications, p 23.

[26] Jemal Nebez (2004), The Kurds History and Culture, London: Western Kurdistan Association Publications.

[27] Jordi Tejel (2009), Syria's Kurds History, politics and Society, New York: Routledge.

[28] Kemal Kirisci, Gareth Winrow (1997), The Kurdish Question and Turkey: an example of a trans-state ethnic conflict, Routledge, $\mathrm{p} 101$.

[29] Le Kurdistan dispose d'environ 3\% des réserves mondiales de pétrole, http://fr.sputniknews.com/, retrieved on 15th November 2017.

[30] Lorenzo Kamel, "Kurdish independence vote: A historical perspective", http://www.aljazeera.com/, retrieved on $4^{\text {th }}$ October 2017.

[31] Yacin Dusman (2014), Remembering the "forgotten" Kurds in Syria, http://www.e-ir.info/, retrieved on $7^{\text {th }}$ November 2017.

[32] Iraqi Autonomous Region is disappointed by the ineffective talks with Bagdad, http://sputniknews.cn/, retrieved on $10^{\text {th }}$ October 2017.

[33] Liu Sherong (2016) "Reasons for Iraqi Kurds' high degree of autonomy and perspectives", "Xin Xibu", No, p 104. (Translation of the authors).

[34] Wang Tieya (1981), Internaltional Law, Law Publishing House, p 61 (Translated by the authors).

[35] Dong Manyuan (2017) "Kurdish issue and the situation of the Middle East", Guoji Wenti Yanjiu, No 4, p 42 (Translated by the authors). 